\title{
A Metaphosphate-dependent Nicotinamide Adenine Dinucleotide Kinase from Brevibacterium ammoniagenes
}

\author{
Kousaku Murata, Tomofumi UChida, Jyoji Kato \\ and Ichiro ChIBATA \\ Research Laboratory of Applied Biochemistry, Tanabe Seiyaku Co., Ltd., \\ 16-89, Kashima-3-chome, Yodogawa-ku, Osaka 532, Japan
}

Received December 17, 1979

\begin{abstract}
The enzyme utilizing metaphosphate for nicotinamide adenine dinucleotide phosphorylation was purified 500-fold from $B$. ammoniagenes and its properties were studied. The isolated enzyme appeared homogeneous on disc gel electrophoresis; its molecular weight was determined to be $9.0 \times 10^{4}$ by gel filtration. This enzyme specifically phosphorylated nicotinamide adenine dinucleotide at the optimum $\mathrm{pH}$ at 6.0. Of phosphoryl donors tested, metaphosphate was most effective for the reaction, and adenosine- $5^{\prime}$-triphosphate was less effective. The activity was inhibited by adenosine-5'-monophosphate, adenosine-5'-diphosphate or reduced pyridine nucleotides. The enzyme did not exhibit catalytic activity in the absence of a divalent cation. We concluded that the enzyme phosphorylating nicotinamide adenine dinucleotide in the presence of metaphosphate is distinct from adenosine-5'-triphosphate-dependent nicotinamide adenine dinucleotide kinase, and tentatively designated it metaphosphate-dependent nicotinamide adenine dinucleotide kinase.
\end{abstract}

In our previous paper, ${ }^{11}$ we described the existence of metaphosphate-utilizing enzyme for nicotinamide adenine dinucleotide phosphorylation. The distribution pattern of this enzyme and enzymatic properties were different from those of adenosine-5'-triphosphate-dependent nicotinamide adenine dinucleotide kinase (EC 2.7.1.23) and phosphotransferase. ${ }^{21}$ To verify the nonidentity of metaphosphate-utilizing enzyme with above two enzyme activities, we isolated this enzyme from $B$. ammoniagenes cells having metaphosphate- and adenosine-5'-triphosphateutilizing activities, but not phosphotransferase activity.

\section{MATERIALS AND METHODS}

Chemicals. Adenosine, adenosine-5'-monophosphate (AMP), adenosine-5'-diphosphate (ADP) and adenosine5 -triphosphate (ATP) were obtained from Kojin Co., Tokyo, Japan. Nicotinamide adenine dinucleotide (NAD), nicotinamide adenine dinucleotide phosphate (NADP) and their reduced forms (NADH and NADPH) were obtained from Oriental Yeast Co., Tokyo, Japan. Adenosine-5'- diphosphate glucose (ADPG), adenosine-5'-diphosphate ribose (ADPR), adenosine-5'mononicotinate (AMN) and flavine adenine dinucleotide (FAD) were obtained from Sigma Chemical Co., St. Louis MO. Trimetaphosphate, tetrametaphosphate and tripolyphosphate were also obtained from Sigma Chemical Co., St. Louis MO. Metaphosphate and polyphosphate were obtained from Katayama Chemical Industries Co., Osaka, Japan. The other chemicals were all analytical grade reagents.

Purification of metaphosphate-dependent NAD kinase from $B$. ammoniagenes. In the following procedures, unless otherwise noted, centrifugation was carried out at $25,000 \times g$ for $30 \mathrm{~min}$, and $5.0 \mathrm{~mm}$ Tris(hydroxymethyl)aminomethane (Tris)- $\mathrm{HCl}$ buffer (pH 7.0) containing $0.5 \mathrm{~mm}$ NAD (Tris-NAD buffer) was used. All procedures were carried out at $0 \sim 4^{\circ} \mathrm{C}$.

1) Preparation of cell extracts. B. ammoniagenes cells were grown on the nutrient medium described previously. ${ }^{11}$ The cells were harvested and washed once with $0.85 \%$ saline solution. After being suspended in Tris-NAD buffer, cells were homogenated on a Dyno-Mill for $10 \mathrm{~min}$, and the homogenate was centrifuged. The extracts thus obtained was fractionated with ammonium sulfate.

2) Ist ammonium sulfate fractionation. Ammonium sulfate $(240 \mathrm{~g})$ was added to the extracts $(1000 \mathrm{ml}, 18.3 \mathrm{~g}$ of protein). After stirring for $30 \mathrm{~min}$, the mixture was centrifuged, and ammonium sulfate $(63 \mathrm{~g})$ was added to the supernatant. After stirring for $30 \mathrm{~min}$, the precipitate was collected by centrifugation and dissolved in $80 \mathrm{ml}$ of Tris- 
NAD buffer. This enzyme solution was dialyzed against the same buffer overnight.

3) 2nd ammonium sulfate fractionation. Ammonium sulfate $(28 \mathrm{~g})$ was added to the dialysate $(100 \mathrm{ml}, 8.75 \mathrm{~g}$ of protein) of 1st ammonium sulfate fraction and the precipitate separated by centrifugation was discarded. To the supernatant, ammonium sulfate $(7.6 \mathrm{~g})$ was added, and a second precipitate was collected by centrifugation and dissolved in $50 \mathrm{ml}$ of Tris-NAD buffer and dialyzed against the same buffer overnight.

4) DEAE-cellulose column chromatography. The dialyzed ammonium sulfate fraction $(75 \mathrm{ml}, 1.43 \mathrm{~g}$ of protein) was applied to DEAE-cellulose column $(5 \times 60 \mathrm{~cm})$ equilibrated with Tris-NAD buffer. The adsorbed protein was eluted with a linear $0 \sim 0.5 \mathrm{M} \mathrm{KCl}$ gradient in Tris-NAD buffer and the effluent was collected as $11 \mathrm{ml}$ portions. The enzyme was eluted with $0.25 \mathrm{M} \mathrm{KCl}$ and the active fractions (tube No. 55 105) were pooled, concentrated ten fold by ultrafiltration (Amicon UM-10 membrane) and then dialyzed against Tris-NAD buffer overnight. The dialysate was concentrated again to $25 \mathrm{ml}$ by ultrafiltration (Amicon UM-10 membrane).

5) 3rd ammonium sulfate fractionation. The enzyme solution $(25 \mathrm{ml}, 0.19 \mathrm{~g}$ protein) from the DEAE-cellulose column was fractionated into five fractions with ammonium sulfate (Fig. 1). The 1st fraction was obtained as follows. The enzyme solution was brought to $20 \%$ saturation by adding $2.8 \mathrm{~g}$ of ammonium sulfate slowly with stirring. After $30 \mathrm{~min}$, the precipitate was collected by centrifugation. 2nd fraction was obtained by adding $1.5 \mathrm{~g}$ ( $30 \%$ saturation) of ammonium sulfate to the supernatant of Ist fraction, and by collecting the precipitates formed after $30 \mathrm{~min}$. In the same manner as employed in the case of 2nd fraction, 3rd, 4th and 5th fractions were obtained successively adding ammonium sulfate to the respective supernatants. The amount of ammonium sulfate added for obtaining $3 \mathrm{rd}$, 4th, and 5 th fractions was $1.5 \mathrm{~g}(40 \%$

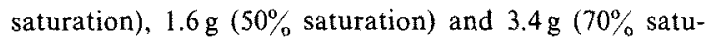
ration), respectively. The precipitates thus obtained were dissolved in $2.0 \mathrm{ml}$ of Tris-NAD buffer and dialyzed against the same buffer overnight. The enzymatic activities of each fraction was determined, and 4th fraction was saved for the further purification.

6) Sephadex G-150 column chromatography. Ammonium sulfate fraction $(3.2 \mathrm{ml}, 21 \mathrm{mg}$ of protein) was applied to a Sephadex G-150 column $(2.5 \times 90 \mathrm{~cm})$ equilibrated with Tris-NAD buffer. Protein was eluted with buffer and the effluent was collected as $4.0 \mathrm{ml}$ portions. The active fractions (tube No. $55 \sim 67$ ) were pooled and concentrated five fold by ultrafiltration (Amicon UM-10 membrane).

7) Hydroxylapatite column chromatography. The concentraed enzyme solution $(10 \mathrm{ml}, 3.7 \mathrm{mg}$ of protein) from the Sephadex G-150 column was applied to a hydroxylapatite column $(1.2 \times 15 \mathrm{~cm})$ equilibrated with $1.0 \mathrm{~mm}$ potassium phosphate buffer ( $\mathrm{pH} 7.0$ ) containing $0.5 \mathrm{mM}$ NAD. Enzyme was eluted with a linear $1.0 \sim 200 \mathrm{~mm}$ potassium phosphate buffer ( $\mathrm{pH} 7.0$ ) containing $0.5 \mathrm{~mm} \mathrm{NAD}$, and the effulent was collected as $2.0 \mathrm{ml}$ portions. The enzyme was eluted at about $0.07 \mathrm{M}$ potassium phosphate buffer $(\mathrm{pH}$ 7.0). The active fractions (tube No. $17 \sim 22$ ) were pooled and dialyzed against $5.0 \mathrm{~mm}$ Tris- $\mathrm{HCl}$ buffer $(\mathrm{pH} 7.0$ ) overnight. The dialysate was concentrated to $1.4 \mathrm{ml}$ by ultrafiltration (Amicon UM-10 membrane) and stored at $-20^{\circ} \mathrm{C}$

Polyacrylamide gels. Disc gel electrophoresis of native enzyme was performed on $6 \mathrm{~cm}$ gels of $7.0 \%$ acrylamide, $0.2 \%$ bisacrylamide, polymerized with $N, N, N^{\prime}, N^{\prime}$ tetramethylethylenediamide and $0.1 \%$ ammonium persulfate. Electrophoresis was performed for $90 \mathrm{~min}$ at $100 \mathrm{mV}(2 \mathrm{~mA} /$ tube $)$ in $25 \mathrm{~mm}$ Tris, $100 \mathrm{~mm}$ glycine buffer (pH 8.0). Gels were stained for protein with Coomassie blue. ${ }^{3)}$

Gel filtration. Molecular weight determination was performed on a column of Sephadex $G-150(1.0 \times 90 \mathrm{~cm})$ by the methods of Andrews. ${ }^{4)}$ The protein was eluted with $5.0 \mathrm{~mm}$ Tris- $\mathrm{HCl}$ buffer $\left(\mathrm{pH} 7.0\right.$ ) at a flow rate of $0.5 \mathrm{ml} / \mathrm{min}$ at $4{ }^{\circ} \mathrm{C}$.

Assay of metaphosphate-dependen NAD kinase activity. The metaphosphate-dependent NAD kinase activity was determined in the following reaction mixture; $10 \mathrm{mg}$ meta phosphate, $2 \mu \mathrm{mol} \mathrm{NAD}, 10 \mu \mathrm{mol} \mathrm{MgCl}_{2}, 50 \mu \mathrm{mol}$ TrisHCl buffer ( $\mathrm{pH} 7.0$ ), and $10 \mu \mathrm{g}$ of enzyme in a volume of $1.0 \mathrm{ml}$. The reaction was allowed to proceed for $20 \mathrm{~min}$ at $37^{\circ} \mathrm{C}$, and NADP formed in reaction mixture was determined by the method described previously." In some experiments, $5 \mu \mathrm{mol}$ ATP was used as phosphoryl donor instead of metaphosphate. In experiments examining inhibition by reduced NADP (NADPH), the reaction was terminated by addition of $0.1 \mathrm{ml}$ of $0.5 \mathrm{M} \mathrm{HCl}$. After $5 \mathrm{~min}$ at room temperature, $0.1 \mathrm{ml}$ of $0.75 \mathrm{M}$ Tris base was added, and the residual NADP was assayed. Specific activity was expressed in terms of nmoles of NADP formed per $\mathrm{mg}$ of protein per hour. Protein was determined by absorbance measurements at $280 \mathrm{~m} \mu\left(A_{1.0 \%}=10.5 \mathrm{~cm}^{-1}\right)$.

\section{RESULTS}

\section{Purification of metaphosphate-dependent NAD kinase from $B$. ammoniagenes}

The metaphosphate-dependent NAD kinase and ATP-dependent NAD kinase activities were successfully separated by 3rd ammonium sulfate fractionation (Fig. 1). In this experiment, NAD phosphorylating activities appeared in two fractions. One precipitated by $30 \sim 40 \%$ saturation with ammonium sulfate and efficiently used ATP as phosphoryl donor. The other active fraction was precipitated by $40 \sim 50 \%$ saturation and efficiently used meta- 


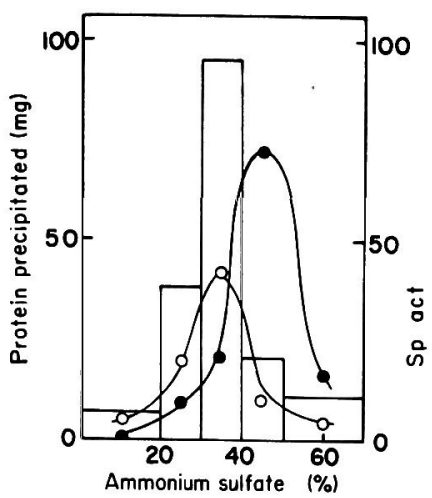

FIG. 1. Separation of Metaphosphate-dependent NAD Kinase and ATP-dependent NAD Kinase.

The partially purified metaphosphate-dependent NAD kinase fraction from DEAE-cellulose column chromatography was further fractionated by ammonium sulfate with the saturation indicated in figure. This figure shows the distribution of activities of two NAD kinases in the presence of metaphosphate $(0)$ and ATP $(O)$ as phosphoryl donors.

phosphate as phosphoryl donor. As summarized in Table I, metaphosphate-dependent NAD kinase was purified about 500 fold from the extracts with recovery of $6.2 \%$ of the initial activity. The purified metaphosphatedependent NAD kinase preparation showed a single band on polyacrylamide gel electrophoresis (Fig. 2). The molecular weight of this enzyme was determined to be $9.0 \times 10^{4}$ by gel filtration on Sephadex G-150 (Fig. 3). The subunit structure of this enzyme was not determined, since the polyacrylamide gel electrophoresis in the presence of sodium dodecyl

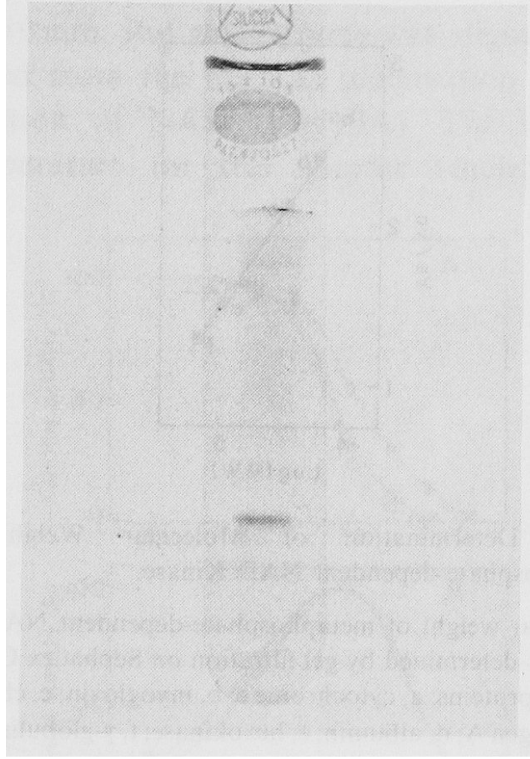

FIG. 2. Disc Gel Electrophoresis of Metaphosphatedependent NAD Kinase.

The methods for the electrophoresis were described in Materials AND Methods. The direction of migration is from the cathode (top of photo) to the anode.

sulfate failed to separare the enzyme more than one component.

\section{Enzymatic properties of metaphosphate- dependent NAD kinase}

1) Phosphoryl donor and acceptor specificity. Phosphoryl donor specificity of metaphosphate-dependent NAD kinase was examined with purified enzyme (Table II). Among the phosphate polymers tested, metaphosphate was specifically utilized by this

Table I. Summary of Purification Procedures

\begin{tabular}{llcccc}
\hline Step & \multicolumn{1}{c}{ Preparation } & $\begin{array}{c}\text { Total protein } \\
(\mathrm{mg})\end{array}$ & Sp act & $\begin{array}{c}\text { Yield } \\
(\%)\end{array}$ & $\begin{array}{c}\text { Ratio of } \\
\text { Sp act }\end{array}$ \\
\hline 1 & Original extracts & 18300 & 1.08 & 100 & 0.54 \\
2 & 1st ammonium sulfate & 8750 & 2.48 & 109 & 1.22 \\
3 & 2nd ammonium sulfate & 1430 & 7.78 & 56.1 & 1.88 \\
4 & DEAE-cellulose & 190 & 46.7 & 44.9 & 2.65 \\
5 & 3rd ammonium sulfate & 21.0 & 139 & 14.6 & 2.85 \\
6 & Sephadex G-150 & 3.96 & 418 & 8.19 & 3.01 \\
7 & Hydroxylapatite & 2.49 & 519 & 6.18 & 2.82 \\
\hline
\end{tabular}

a Ratio: specific activity for metaphosphate/specific activity for ATP. The details of purification were described in Methods and Materials. 


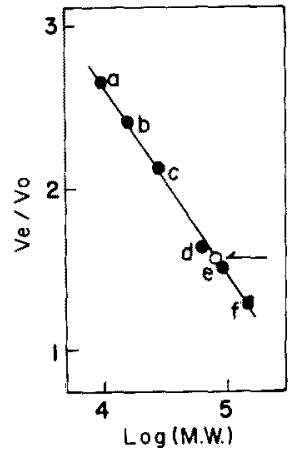

Fig. 3. Determination of Molecular Weight of Metaphosphate-dependent NAD Kinase.

Molecular weight of metaphosphate-dependent NAD kinase was determined by gel filtration on Sephadex G-150. Marker proteins: a, cytochrome c; b, myoglovin; c, chymotrypsinogen $A ; d$, albumin; $e$, hexokinase; $f, \gamma$-globulin. The position of metaphosphate-dependent NAD kinase was shown by arrow. $V o$ and $V e$ are void volume of column and elution volume of protein, respectively.

enzyme, and other ring or chain phosphate polymers were not utilized as phosphoryl donors. However, intrinsic phosphoryl donor in metaphosphate could not be determined, since the metaphosphate was a mixture of various ring phosphate polymers. In addition to metaphosphate, this enzyme utilized ATP as phosphoryl donor. $p$-Nitrophenylphosphate, which
Table II. Phosphoryl Donor Specificity of METAPHOSPHATE-DEPENDENT NAD KINASE

Activities were assayed under standard assay conditions except that the various phosphoryl donors were used at the indicated concentrations.

\begin{tabular}{lcl} 
Phosphoryl donor & Concentration & $\begin{array}{c}\text { NADP } \\
\text { formed } \\
\text { (mM) }\end{array}$ \\
\hline Pyrophosphate & $5.0 \mathrm{~mm}$ & 0 \\
Tripolyphosphate & $1.0 \mathrm{mg} / \mathrm{ml}$ & 0 \\
Polyphosphate & $10 \mathrm{mg} / \mathrm{ml}$ & 0 \\
& $1.0 \mathrm{mg} / \mathrm{ml}$ & 0 \\
Trimetaphosphate & $10 \mathrm{mg} / \mathrm{ml}$ & 0 \\
Tetrametaphosphate & $1.0 \mathrm{mg} / \mathrm{ml}$ & 0 \\
& $10 \mathrm{mg} / \mathrm{ml}$ & 0 \\
Metaphosphate & $1.0 \mathrm{mg} / \mathrm{ml}$ & 0 \\
& $10 \mathrm{mg} / \mathrm{ml}$ & 0 \\
& $1.0 \mathrm{mg} / \mathrm{ml}$ & 0.16 \\
ATP & $10 \mathrm{mg} / \mathrm{ml}$ & 0.11 \\
& $0.5 \mathrm{~mm}$ & 0.03 \\
& $2.0 \mathrm{~mm}$ & 0.07 \\
& $5.0 \mathrm{~mm}$ & 0 \\
& $10 \mathrm{~mm}$ & 0 \\
\hline
\end{tabular}

is a substrate utilized by acid phosphatase ${ }^{2 y}$ for the phosphorylation of NAD, was not utilized by metaphosphate-dependent NAD kinase.

Phosphoryl acceptor specificity of this en-

TAble III. Phosphoryl AcCeptor Specificity of Metaphosphate-dependent NAD Kinase

\begin{tabular}{|c|c|c|c|c|c|c|c|c|}
\hline \multirow{2}{*}{$\begin{array}{l}\text { Phosphoryl } \\
\text { acceptor } \\
(5 \mathrm{~mm})\end{array}$} & \multicolumn{4}{|c|}{ Rf values of phosphoryl acceptor } & \multicolumn{4}{|c|}{ Rf values of phosphorylated compounds } \\
\hline & I & II & III & $\mathrm{IV}^{a}$ & I & II & III & IV \\
\hline Adenosine & 0.94 & 0.71 & 0.14 & - & N.D. ${ }^{b}$ & N.D. & N.D. & - \\
\hline AMP & 0.77 & 0.54 & 0.34 & - & N.D. & N.D. & N.D. & - \\
\hline $\mathrm{ADP}$ & 0.67 & 0.42 & 0.39 & - & N.D. & N.D. & N.D. & - \\
\hline$A D P G$ & 0.62 & 0.61 & 0.41 & - & N.D. & N.D. & N.D. & - \\
\hline ADPR & 0.65 & 0.64 & 0.38 & - & N.D. & N.D. & N.D. & - \\
\hline $\mathrm{AMN}$ & 0.94 & 0.79 & 0.10 & - & N.D. & N.D. & N.D. & - \\
\hline NAD & 0.75 & 0.48 & 0.30 & - & $\begin{array}{c}0.63 \\
(0.62)\end{array}$ & $\begin{array}{c}0.30 \\
(0.31)\end{array}$ & $\begin{array}{c}0.46 \\
(0.47)^{c}\end{array}$ & - \\
\hline FAD & - & - & - & 0.14 & 一 & -- & - & N.D. \\
\hline
\end{tabular}

a Following solvent systems were used for the detection of phosphorylated compounds: 1 , isobutyrate-0.5 $\mathrm{N}$ $\mathrm{NH}_{4} \mathrm{OH}(5: 3 \mathrm{v} / \mathrm{v}) ; \mathrm{II}, 95 \%$ ethanol-1.0 M CH $\left.\mathrm{CHONa}_{3} \mathrm{CO}: 3 \mathrm{v} / \mathrm{v}\right)$; III, saturated $\left(\mathrm{NH}_{4}\right)_{2} \mathrm{SO}_{4}-0.1 \mathrm{M} \mathrm{CH} \mathrm{COONa}_{3}$ isopropanol $(40: 10: 1 \mathrm{v} / \mathrm{v})$; IV, buthanol-- $\mathrm{CH}_{3} \mathrm{COOH}-\mathrm{H}_{2} \mathrm{O}(4: 1: 1 \mathrm{v} / \mathrm{v})$.

b Phosphorylated compounds were not detected.

c Rf values of authentic NADP.

Purified enzyme solution was dialyzed against $5 \mathrm{~mm}$ Tris-HCl buffer ( $\mathrm{pH} 7.0$ ) overnight, and then used for the reaction. 
zyme was also investigated using metaphosphate as phosphoryl donor (Table III). Among the compounds tested, only NAD was phosphorylated by this enzyme, and the phosphorylation product was NADP only. This was confirmed by the following facts; (1) $R f$ values of the product on several paperchromatograms with different solvent systems were the same as that of authentic NADP, (2) the product was completely reduced by the reaction of glucose-6-phosphate dehydrogenase or isocitrate dehydrogenase.

2) $p H$ optimum and $p H$ stability. The $\mathrm{pH}$ optimum of metaphosphate-dependent NAD kinase reaction was around 6.0, and this enzyme was stable at the $\mathrm{pH}$ range of 5.0 to 6.0 (Fig. 4). The same pattern of $\mathrm{pH}$-activity and $\mathrm{pH}$-stability profiles were obtained in both cases of phosphoryl donors, metaphosphate and ATP.

3) Effect of temperature on stability and activity. The effects of temperature on stability and activity of metaphosphate-dependent NAD kinase were examined using metaphosphate and ATP as phosphoryl donors (Fig. 5). This enzyme was rapidly inactivated above $40^{\circ} \mathrm{C}$ and completely lost the activity at $57^{\circ} \mathrm{C}$

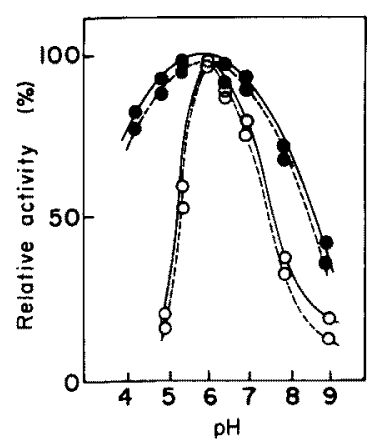

FIG. 4. $\mathrm{pH}$ Optimum and $\mathrm{pH}$ Stability of Metaphosphate-dependent NAD Kinase.

In the studies of $\mathrm{pH}$ optimum, reaction was carried out under various $\mathrm{pH}$ values in the presence of metaphosphate $(-\mathrm{O}-)$ and ATP (--O--). In the studies of $\mathrm{pH}$ stability, enzyme was incubated at $40^{\circ} \mathrm{C}$ for $10 \mathrm{~min}$ in $0.02 \mathrm{M}$ buffer with various $\mathrm{pH}$ values. Aliquots of incubation mix ture were adjusted to $\mathrm{pH} 7.0$, and assayed the residual activity using metaphosphate (- - ) or ATP (-- - ) ) pH was adjusted to the indicated value with Tris-maleate buffer. for $10 \mathrm{~min}$. But this enzyme was slightly protected from the thermal inactivation by the addition of NAD (Fig. 5A). The optimal temperature for this enzyme reaction was
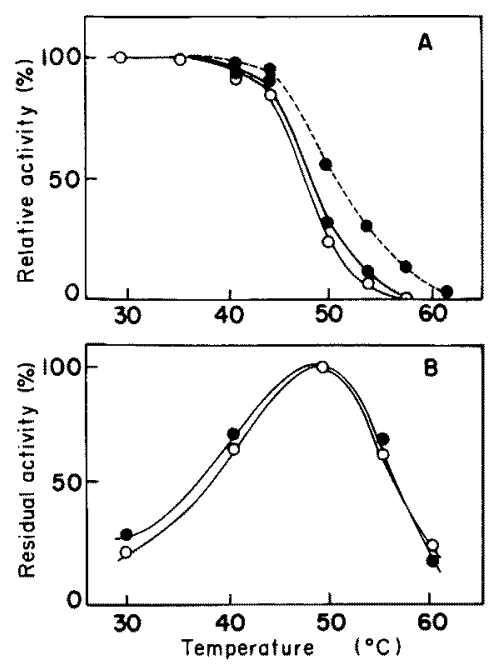

FIG. 5. Thermal Stability of Metaphosphate-dependent NAD Kinase (A) and Optimal Temperature for Activity (B).

A; The enzyme solution equilibrated with $5 \mathrm{~mm}$ Tris- $\mathrm{HCl}$ buffer ( $\mathrm{pH} 7.0$ ) was treated at the indicated temperature for $10 \mathrm{~min}$ with (--) or without $(-) 5.0 \mathrm{~mm} \mathrm{NAD}$, and the residual activities were assayed using metaphosphate $(O)$ or ATP (O).

$B$; In the studies of temperature optimum, reaction was carried out at the indicated temperature for $2 \mathrm{~min}$ using metaphosphate (O) or ATP $(O)$ as phosphoryl donors.

TABle IV. EFFect of Metal IONS ON MetaphosphateDEPENDENT NAD KINASE ACTIVITY

\begin{tabular}{lcc}
\hline Metals & $\begin{array}{c}\text { Concentration } \\
(\mathrm{mM})\end{array}$ & $\begin{array}{c}\text { Relative } \\
\text { activity }(\%)^{a}\end{array}$ \\
\hline None & & 0 \\
$\mathrm{MgCl}_{2}$ & 5 & 100 \\
& 30 & 140 \\
$\mathrm{MnCl}_{2}$ & 60 & 176 \\
& 5 & 100 \\
$\mathrm{CaCl}_{2}$ & 30 & 135 \\
& 5 & 120 \\
$\mathrm{CoCl}_{2}$ & 30 & 165 \\
$\mathrm{NiCl}_{2}$ & 5 & 1.7 \\
$\mathrm{ZnCl}_{2}$ & 5 & 0.9 \\
$\mathrm{HgCl}_{2}$ & 5 & 4.6 \\
\hline
\end{tabular}

a Relative activities were based on the $100 \%$ activity in the presence of $5 \mathrm{mM} \mathrm{MgCl}$. 


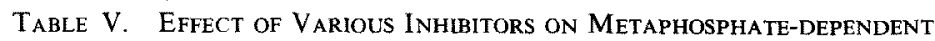
NAD KINASE ACTIVITY

Reaction was carried out under standard assay conditions with or without various inhibitors.

\begin{tabular}{|c|c|c|c|c|}
\hline Addition (mM) & & $\begin{array}{c}\text { Relative } \\
\text { activity }(\%)\end{array}$ & $\begin{array}{l}\text { Type of } \\
\text { inhibition }\end{array}$ & $\begin{array}{c}K i \\
(\mathrm{mM})\end{array}$ \\
\hline None & & 100 & & \\
\hline \multirow[t]{2}{*}{ Adenosine } & 1.0 & 100 & & \\
\hline & 10 & 100 & & \\
\hline \multirow{2}{*}{ AMP } & 1.0 & 95.0 & \multirow{2}{*}{ Competitive } & \multirow{2}{*}{9.80} \\
\hline & 6.0 & 71.0 & & \\
\hline \multirow{2}{*}{ ADP } & 0.1 & 75.4 & \multirow{2}{*}{ Competitive } & \multirow{2}{*}{0.58} \\
\hline & 0.2 & 67.1 & & \\
\hline$A D P G$ & 0.5 & 65.4 & \multirow{11}{*}{ Competitive } & \multirow{11}{*}{0.43} \\
\hline ADPR & 0.5 & 66.2 & & \\
\hline NADH & 0.5 & 72.1 & & \\
\hline NADPH & 0.5 & 53.3 & & \\
\hline Iodoacetate & 1.0 & 88.0 & & \\
\hline $\mathrm{HgCl}_{2}$ & 0.5 & 0 & & \\
\hline$p$-Chloromercurybenzoate & 0.1 & 0 & & \\
\hline Pyrophosphate & 5.0 & 97.8 & & \\
\hline Tripolyphosphate & 2.0 & 95.8 & & \\
\hline Trimetaphosphate & 2.0 & 97.5 & & \\
\hline Tetrametaphosphate & 2.0 & 98.6 & & \\
\hline
\end{tabular}

around $50^{\circ} \mathrm{C}$. (Fig. 5B).

4) Metal requirement. Divalent metal ions were indispensably required for this enzyme reaction as shown previously. ${ }^{1 /}$ Of the metal ions tested, $\mathrm{Ca}^{2+}, \mathrm{Mg}^{2+}$, and $\mathrm{Mn}^{2+}$ were more potent activator than others. The activity was strongly dependent on the concentration of these metal ions and increased with the concentration (Table IV). But the reaction did not proceed at the concentration above $70 \mathrm{~mm}$ of $\mathrm{Mg}^{2+}$, since the precipitate was formed.

5) Effect of inhibitors on enzyme activity. The effect of various inhibitors on metaphosphate-dependent NAD kinase activity was investigated (Table V). This enzyme reaction was inhibited by AMP, ADP, NADH, NADPH and sulfhydryl reagents such as $\mathrm{HgCl}_{2}$, and $p$-chloromercurybenzoate. Of these inhibitors tested, inhibition by AMP, ADP, and NADPH were competitive with NAD. On the other hand, adenosine and ring or chain phosphate polymers of low molecular weight showed no inhibition.
6) Kinetics. The effect of metaphosphate concentration on reaction rate was examined. The reaction proceeded efficiently at concentrations up to $1.0 \mathrm{mg} / \mathrm{ml}$. Above this concentration, metaphosphate inhibited the reaction (Fig. 6). The $\mathrm{Km}$ values for NAD with $1.0 \mathrm{mg} / \mathrm{ml}$ and $10 \mathrm{mg} / \mathrm{ml}$ of metaphosphate

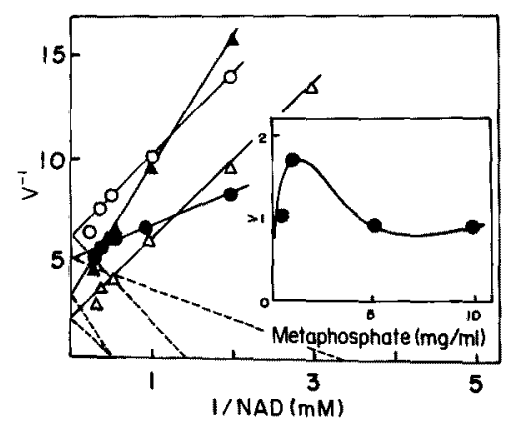

FIG. 6. Dependence of Reaction Rate on NAD and Metaphosphate (Inset Figure) Concentrations.

Dependence of reaction rate on NAD concentration was determined in the presence of metaphosphate or ATP. Velocities are in arbitrary units. Symbols: metaphosphate $1.0 \mathrm{mg} / \mathrm{ml}(O), 10 \mathrm{mg} / \mathrm{ml}(\mathrm{O}) ;$ ATP $1.0 \mathrm{~mm}$ (A), $2.0 \mathrm{mM}$ $(\Delta)$ 


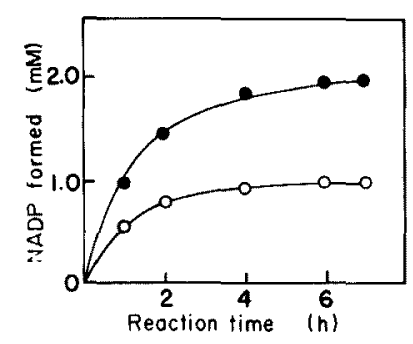

FiG. 7. Time Course of Metaphosphate-dependent NAD Kinase Reaction.

Reaction was proceeded under standard assay conditions, except for the concentration of metaphosphate: $25 \mathrm{mg} / \mathrm{ml}$ (O); $50 \mathrm{mg} / \mathrm{ml}$

were $3.0 \times 10^{-4} \mathrm{M}$ and $6.2 \times 10^{-4} \mathrm{M}$, respectively. On the other hand, the $K m$ value for NAD in the presence of ATP as phosphoryl donor was $2.3 \times 10^{-3} \mathrm{M}$. The $\mathrm{Km}$ values for intrinsic substrate in metaphosphate, however, could not be determined, since we could not isolate these substrates in pure state. The $K m$ value for ATP was $6.7 \times 10^{-3} \mathrm{M}$.

The reaction proceeded completely in the direction of NADP formation, and about $25 \mathrm{mg}$ of metaphosphate was required for the conversion of $1.0 \mu \mathrm{mol}$ of NAD to NADP (Fig. 7).

\section{DISCUSSION}

In many microorganisms, NADP has been synthesized by two enzymes, ATP-dependent NAD kinase and phosphotransferase (i.e. reverse reaction of acid phosphatase). However, in the course of our studies on the utilization of energy in phosphate polymers, we recognized an activity utilizing metaphosphate for NAD phosphorylation in $B$. ammoniagenes. ${ }^{11}$

It seems certain that the metaphosphateutilizing activity for NAD phosphorylation is different from the phosphotransferase activity, since the distribution pattern of metaphosphate-utilizing activity was quite different from that of phosphotransferase activity reported by Ogata et al. ${ }^{2)}$ Furthermore, metaphosphate-utilizing enzyme for NAD phosphorylation differed from phosphotransferase in some enzymatic properties. For exam- ple, the reaction product of metaphosphateutilizing enzyme was NADP only, though the phosphotransferase reaction produces biologically inactive NADP analogues in addition to NADP. ${ }^{5}$

But the distribution pattern on metaphosphate-utilizing activity for NAD phosphorylation was closely similar to that of polyphosphate glucokinase activity. ${ }^{6)} \mathrm{B}$. ammoniagenes has polyphosphate glucokinase and metaphosphate-utilizing enzyme for NAD phosphorylation. However, these two enzyme activities were clearly separated by DEAEcellulose column chromatography (unpublished data). Therefore, the most interesting point was whether or not the metaphosphateutilizing enzyme for NAD phosphorylation is the same enzyme as an ATP-dependent NAD kinase. So we attempted to purify the former enzyme from $B$. ammoniagenes.

In analogy with an ATP-dependent NAD kinase of various sources, the purified metaphosphate-utilizing enzyme required metal ions for activity, and was inhibited by adenosine nucleotides or reduced pyridine nucleotides. This enzyme was also inhibited by sulfhydryl reagents. Furthermore, contrary to our expectation, this enzyme used ATP besides metaphosphate. These facts make it difficult to discriminate this enzyme from an ATPdependent NAD kinase. The possibility that the isolated metaphosphate-utilizing enzyme is a subunit of original ATP-dependent NAD kinase has not been excluded.

From the following facts, however, it was strongly suggested that this enzyme is different from an ATP-dependent NAD kinase. (1) the distribution pattern of two enzyme activities is different. ${ }^{1 \prime}$ (2) these two enzymes in crude extracts showed quite different activity with respect to $\mathrm{pH}$ and temperature. ${ }^{1}$ ( $(3)$ the activity ratio of two kinases changed by culture conditions. ${ }^{11}$ (4) these two enzyme activities were separated by ammonium sulfate fractionation (Fig. 1). (5) in the course of purification after ammonium sulfate fractionation, the ratio of metaphosphate $v s$. ATP dependent NAD kinase activity remained constant. (6) the mo- 
lecular weight of metaphosphate utilizing enzyme was smaller in comparison with that of ATP-dependent NAD kinase of sea urchin egg $\left(3.1 \times 10^{5}\right),{ }^{7}$ pigeon liver $\left(2.7 \times 10^{5}\right){ }^{8)}$ Azotobacter vinelandii $\left(1.3 \times 10^{5},{ }^{9)}\right.$ and rabbit liver $\left(1.36 \times 10^{5}\right){ }^{10}$ Therefore, we considered this enzyme to be different from ATPdependent NAD kinase, and we designated this enzyme as metaphosphate-dependent NAD kinase.

This enzyme possibly is involved in the regulation of intracellular NADP level and in the metabolism of phosphate polymers in microorganisms. Furthermore, it is also clear that the certain phosphate polymers could perform the functions usually inherent to ATP, since many enzymes utilizing phosphate polymers for phosphorylation of biological molecules are known in microorganisms. Such enzymes are polyphosphate kinase, ${ }^{11}$ polyphosphate glucokinase, ${ }^{12)}$ polyphosphate fructokinase, ${ }^{13)}$ polyphosphate-AMP phosphotransferase ${ }^{14)}$ and metaphosphate-dependent NAD kinase presented in this paper. In addition to these enzymes, recently we found the metaphosphate utilizing activity for phosphorylation of cytidine- 5 -monophosphate to cytidine- 5 'triphosphate in extracts of Enterobacter aerogenes (unpublished data). Other enzymes utilizing certain phosphate polymers as phosphoryl donor are expected to exist in microorganisms. Therefore, it is necessary to study not only the biosynthetic and degradative pathways of phosphate polymers, but also the content of them in microorganisms for the elucidation of the basic functions of phosphate polymers with respect to the energy supply.

Acknowledgment. We thank for M. Hosoda for her technical assistances.

\section{REFERENCES}

1) K. Murata, K. Tani, J. Kato and I. Chibata, Agric. Biol. Chem., 44, 61 (1980).

2) T. Tochikura, M. Kuwahara, T. Tachiki and K. Ogata, Agric. Biol. Chem., 36, 745 (1972).

3) A. Chrambach, R. A. Reisfeld, M. Wyckoff and J. Zaccari, Anal. Biochem., 20, 150 (1967).

4) P. Andrews, Biochem. J., 96, 595 (1968).

5) T. Tochikura, M. Kuwahara, S. Komatubara, M. Fujisaki, A. Suga and K. Ogata, Agric. Biol. Chem., 33, 840 (1969).

6) K. Murata, J. Kato and I. Chibata, Agric. Biol. Chem., 42, 222 I (1978).

7) C. H. Blomquist, J. Biol. Chem., 248, 7044 (1973).

8) D. K. Apps, Eur. J. Biochem., 55, 475 (1975).

9) A. E. Chung, Biochem. Biophys. Acta, 159, 490(1968).

10) A. E. Chung, "Methods in Enzymology," Vol. 18 (part B), 1971, p. 149 156.

11) A. Kornberg, S. R. Kornberg and E. S. Simms, Biochem. Biophys. Acta, 26, 215 (1956),

12) M. Szymona, O. Szymona and S. Kulesza, Acta Microbiol. Polon., 11, 287 (1962).

13) O. Szymona, and T. Szumilo, Acta Biochim. Polon., 17, 129 (1966).

14) G. Dirheimer and J. P. Ebel, Compt. Rend., 260, 3787 (1965) 